\title{
Stadium Architecture and Regional Economic Development: International Experience and the Plans of Durban
}

\author{
Wolfgang Maennig $^{\dagger}$ and Florian Schwarthoff ${ }^{\dagger}$
}

August 2008

\begin{abstract}
For the FIFA World Cup 2010, South Africa plans to invest heavily. The positive economic effects that the country is hoping for stand in contrast to almost all statistical ex-post studies. This contribution emphasises that these results, usually from research under-taken in the USA, can only be generalised to a limited degree. The density of sports venues in developed countries is so high, that the marginal effects of new stadia are necessarily limited. We also emphasise that stadium design around the world was not hitherto adequately targeted towards positive economic effects. The example of Durban and its plans for a new "iconic" stadium is used to illustrate fundamental principles of stadium design and their embedding in a re-urbanisation process that have to be undertaken in order to consciously achieve positive regional economic effects.
\end{abstract}

\section{JEL Classification Codes: L83}

Keywords: Demand for sport, soccer, mono-functional arenas, multifunctional stadia

This paper is also available as Hamburg Contemporary Economic Discussions, No. 04-2006.

${ }^{\dagger}$ University of Hamburg, Chair for Economic Policy, Von-Melle-Park 5, 20146 Hamburg, Germany, E-mail: maennig(a,econ.uni-hamburg.de, phone: +49 (0)40 42838 - 4622, fax: +49 (0)40 42838 - 6251

${ }^{\dagger}$ GMP Gerkan Marg \& Partners International Hardenbergstrasse 4-5, D-10623 Berlin, Germany, Tel +49 30 614855, fschwarthoff@gmp-architekten.de 


\title{
Stadium Architecture and Regional Economic Development: International Experience and the Plans of Durban
}

\begin{abstract}
For the FIFA World Cup 2010, South Africa plans to invest heavily. The positive economic effects that the country is hoping for stand in contrast to almost all statistical ex-post studies. This contribution emphasises that these results, usually from research under-taken in the USA, can only be generalised to a limited degree. The density of sports venues in developed countries is so high, that the marginal effects of new stadia are necessarily limited. We also emphasise that stadium design around the world was not hitherto adequately targeted towards positive economic effects. The example of Durban and its plans for a new "iconic" stadium is used to illustrate fundamental principles of stadium design and their embedding in a re-urbanisation process that have to be undertaken in order to consciously achieve positive regional economic effects.
\end{abstract}

Keywords: stadium architecture, regional economics, sports economics, World Cup, Durban

\section{Introduction}

The FIFA World Cup 2010 is to be held in South Africa, one of the most developed and wealthy nations on the African continent. This festival will signify a fascinating future, especially to the youth of the country. In spite of its relatively high stage of development, South Africa will have to invest heavily. According to current figures, the South African government intends to spend $€ 627$ million on the ten stadia and $€ 1.6$ billion on infrastructure (Dengel, 2006; Powell, 2006). Section 2 summarizes the current state of planning and compares it with recent experiences in Germany. However, high costs and/or resource expenditure for sport and sport stadia on the one hand are not necessarily accompanied by corresponding economic benefits on the other: as a rule, academic research on the basis of econometric ex-post evaluations tend to find hardly any significantly positive income and employment effects from World Cups, Olympic Games, other largescale sporting events and/or the associated investments in stadia. On the contrary, in some cases, they even find significantly negative effects. In Section 3 of 
the present contribution, we show that ex-ante economic impact studies of World Cups always arrive at positive economic effects on the (regional) economy, whilst econometric ex-post studies almost exclusively arrive at non-significant or even negative effects. Section 4 depicts the reasons for the hitherto unsatisfactory results -from a sporting perspective - and adduces two arguments two expand the discussion, arguments which simultaneously make it clear that the predominantly pessimistic results of previous studies cannot be generalised. On the one hand we emphasise that the previous studies related to industrialised countries in which a high density of sports venues already existed. Given that sports venues are also subject to the law of diminishing returns, at most low-level effects are to be expected. On the other hand we emphasise that the stadia in the cities examined were not adequately designed with the objective of positive regional economic growth in mind. In Section 5 we discuss the case of the city of Durban, which is attempting to implement the appropriate consequences for its 2006 World Cup stadium by imparting it with functionality for urban planning and the regional economy via a consciously "iconic" architecture. In this context we also make it clear that the relevant design should not be limited to the stadium itself, but has to be embedded in a design concept for the entire urban region, a concept which needs to be newly defined. Furthermore, we also illustrate the fact that the process of re-urbanisation of a neglected region via stadium construction cannot be understood as a short-term initiative. Rather, the development of such an area must be seen as a process taking many years and made up of several different stages or frameworks. Emphasis is also placed on the central role of the issues of sustainability, ecology and economy, without which a longterm developmental process will find it hard to survive. Section 6 concludes.

\section{South Africa's investment plans for the soccer World Cup 2010}

Ten stadia are planned in nine host cities (illustration 1 ). All the stadia possess the minimum capacity of 40,000 spectators as required by the World Football Association FIFA. Five stadia (Soccer City and Ellis Park in Johannesburg, Royal Ba- 
fokeng in Rustenberg, Loftus Versfeld in Pretoria and Free State in Bloemfontein) will be adapted to FIFA's quality requirements via modernisation measures. Another five stadia (Capetown, Durban, Nelspruit, Port Elisabeth) will be newly built. These new stadia also include the projects in Durban and Capetown, where the new buildings will replace the existing stadia.

The regional distribution of the stadia shows a certain concentration in and around South Africa's major metropolis, Gauteng, whereas Green Point, Nelson Mandela and King's Park will be located in the coastal area.

Political factors will probably have played a role during the selection of the investment locations (Maennig, 2006b), which can also be inferred from remarks made by the Deputy Sport and Recreation Minister Gert Oosthuizen such as "The spread of the announced stadiums indicates that government acted swiftly to scrap the imbalance between rugby and soccer fields" and "furthermore, we have tilted the ownership scales in respect of stadiums in favour of the people" (both quotes from N.N. 2006). It should be added that soccer is far and away the most popular sport among the black population. The white population by contrast favours cricket and rugby and has only a limited interest in soccer. Up till now most of the large stadia have been owned by the "white" cricket and rugby clubs. The South African government is awaiting finalisation of the contracts with owners of the existing stadia, while the five new structures will be owned by the relevant municipalities.

The strong political influence on the decision of allocation of (stadia) investments means that economic efficiency is not the most important argument. This has to be taken into account when the economic effects of the stadia investments will be evaluated at a later stage. 
Fig. 1: Localisation of the ten soccer World Cup stadia in South Africa

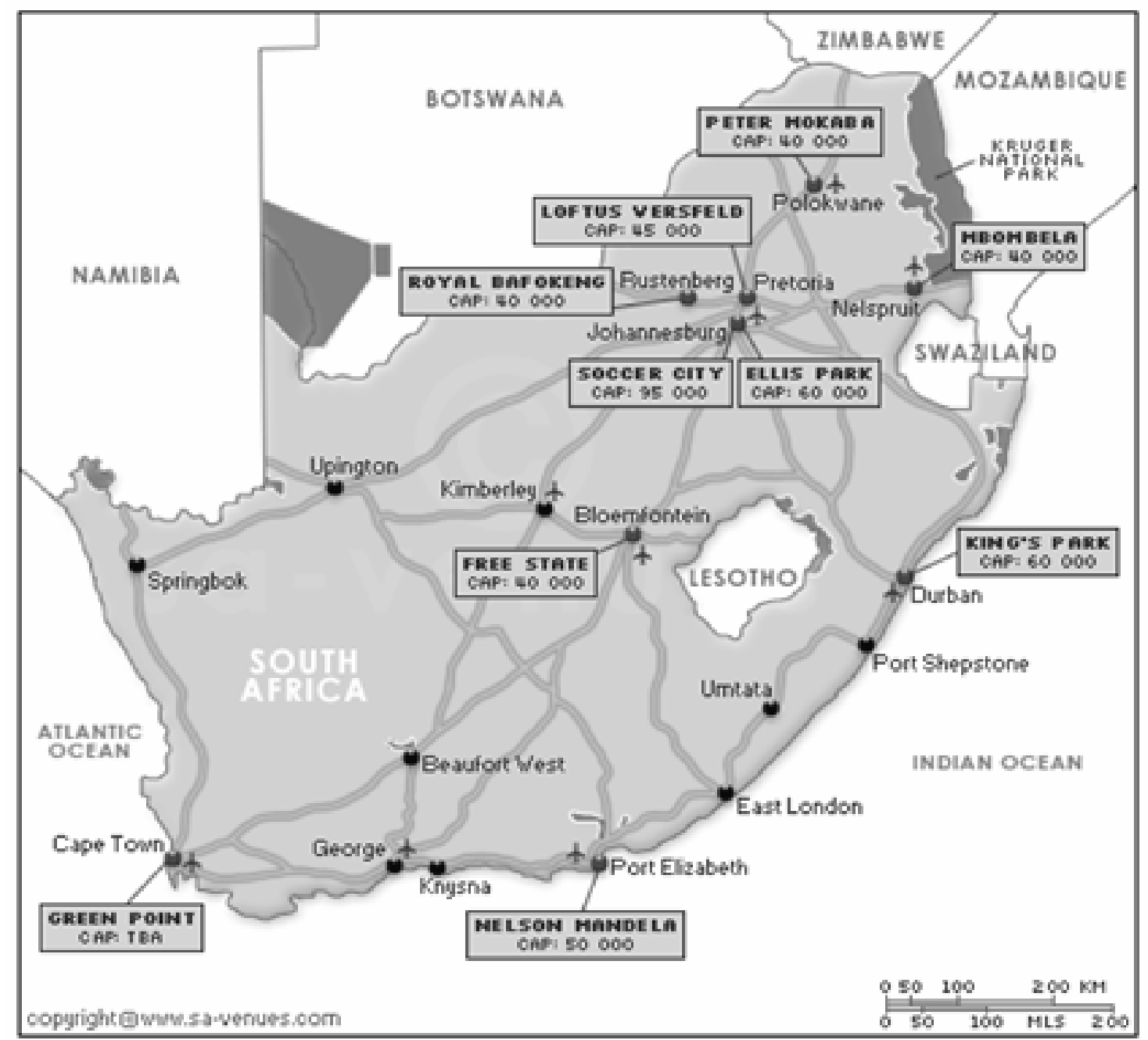

Source: http://www.sa-venues.com/2010/2010-stadium.htm from 19th July 2006

In one of the first South African studies, the expected figure for expenditure for the ten stadia was calculated at $€ 202$ million $^{1}$ and around $€ 56$ million for infrastructure (Grant Thornton, 2004). The cost estimates for the new stadiums in Durban, P.E., and Cape Town are now at $€ 180, € 79$, and $€ 180$ million). In the meantime the South African government has declared that it now intends to spend $€ 561$ million for the ten stadia (Powell, 2006). The estimates for the infrastructure have also been increased to $€ 1.6$ billion (Dengel, 2006). Incidentally, further increases in expenditure may be on the way: In Germany around $€ 1.4$ billion was spent on stadia - albeit in twelve World Cup locations (Du Plessis, Maen-

1 Conversion on the basis of the R/€-exchange of 21st of July, 2006 (8.91 R/€). 
nig, 2006). For the 2002 World Cup, South Korea spent nearly US- $\$ 2$ billion, and Japan at least US-\$ 4 billion for the stadia (Baade, Matheson, 2004a: 345).

Attention should of course be drawn to the fact that the experiences in Korea, Japan and Germany should be seen against the background of possible exchange rate distortions, different labour costs, different technical requirements, ${ }^{2}$ different political structures and financial conditions ${ }^{3}$ and cannot be directly applied to the situation in South Africa. This having been said, we would like to draw the reader's attention to two phenomena in connection with investments in Germany. Firstly, against the background of South Africa's ambitions for stadium architecture with particular urban development effects, it should be pointed out that Munich's Allianz Arena, the one German stadium able to display "iconic" architecture, cost around R2.5 billion ( $€ 280$ million), making it the most expensive stadium project.

Secondly it must be emphasised that around $€ 2$ billion was spent on World Cup related infrastructure in Germany (Maennig, Buettner, 2006). The infrastructure costs were thus significantly higher than the stadium costs, although the infrastructure that is relevant for large-scale sporting events (motorways and motorway junctions, railway platforms, car parks) already exists to a relatively high degree in Germany. There is thus every reason to pay the highest attention to the infrastructure costs, which are unlikely to be any lower than stadium investments.

2 The climatic conditions in Germany for example meant that all the spectator areas had to be roofed. In the case of a large number of "arenas" the decision was taken to build completely roofed stadia or stadia with closeable roofing. In South Africa this is only envisaged in Cape Town.

3 Note that the German public deficit is at more than $3 \%$ of GDP and public debt is significantly over $60 \%$ of GDP, whereas South African public deficit is at less than $2 \%$ of GDP and public debt is significantly below $40 \%$ of GDP. 


\section{The economics of Soccer World Cups}

In addition to the above-described expenditure impulses due to construction activities, additional income and employment effects can also be expected from the expenditure of the Organising Committee (e.g. marketing and PR, security, catering, transport) as well as the activities of visitors from elsewhere (tourists and World Cup teams together with their entourages). ${ }^{4}$ Expenditure from tourists is primarily related to the accommodation and catering sectors, transport and retailing (merchandising and souvenirs).

Long-term effects of the organisation of the World Cup such as potentially positive political effects, image effects, ${ }^{5}$ structural and growth effects also need to be taken into consideration. These may be triggered firstly because the staff of the Organisation Committees and the authorities involved, as well as the volunteers, all gain an increase in know-how, e.g. foreign language skills, intercultural experience, new skills in relation to IT and communications systems. Secondly, urban infrastructure receives a fresh impetus, particularly in relation to sports facilities, but also with regard to public transport systems, the transport infrastructure in general and telecommunications facilities. Thirdly, the cities hope to achieve "image effects" which generate increased numbers of private and conference tourists, as well as more (external) investments (Jasmand, Maennig, 2006).

Econometric works on the effects of sporting events such as the Olympic Games, sports leagues such as the Major Leagues in the USA and/or sports stadia mostly come to the conclusion that the sporting events or sports stadia have no significant impacts on regional income and/or employment (eg. Baade 1994 and 1996, Baade and Sanderson 1997, Baade and Matheson 2000, Coates and Humphrey 2000b). A number of works, particularly those of Baade (1987), Baade and Dye

\footnotetext{
In a macro-economic analysis of the additional impulses for the World Cup region with correct with and without cases, the expenditure of the local World Cup spectators ought not to be included, since they would pursue other activities involving expenditure if the World Cup were not taking place. Hitherto no indication exists that the local population spends more during the World Cup than it would otherwise.

For a description of the methods for the quantification and monetarisation of this kind of image effect cf. Maennig and Feddersen (2002).
} 
(1990), Coates and Humphreys (1999, 2000a, 2003), Baade and Matheson (2002), even arrive at significant negative effects. To our knowledge, only very few studies find significant positive effects. Baim (1994) finds positive employment effects of Major League Baseball and Football for 15 cities in the US. Kang and Perdue (1994) find that the Olympic Games of Seoul 1988 led to 1 million additional arrivals and US\$ 1.3 billion additional income from tourism in Korea. Hotchkiss, Moore, and Zobey (2003) find significant positive employment effects on regions in Georgia (USA) affiliated or close to Olympic activities of the Games in 1996, but they did not find significant wage effects. Carlinho and Coulson (2004) find positive effects of NFL teams on central on housing rents, but no significant increase in wages and interpret this finding as positive effects of NFL sports. Tu (2005) finds significant positive effects of the FedEx Field (Washington) on real estate prices of its neighbourhood. Finally Jasmand and Maennig (2006) find positive income effects for German regions which hosted the Olympic Games of 1972, but no employment effects. ${ }^{6}$

The only two econometric studies published so far which elaborate on soccer World Cups do not form an exception to the generally pessimistic view on the economic effects of sports events. Szymanski (2002) collected data on the twenty largest economies measured by current GDP over the last thirty years. Many of these countries have hosted the Olympic Games or the World Cup at least once in the past 30 years. Using a simple regression he comes to the conclusion that the growth of these countries is significantly lower in World Cup years. 'Baade and Matheson (2004a) show that for the 1994 World Cup in the USA, 9 of the 13 host cities suffered falls in growth. Overall the 13 locations suffered losses on balance of over US\$ 9 billion.

6 In addition to econometric analysis with "realised data", there are studies for perceived benefits, see Kim/ Petrick (2005) and Kim/ Gursoy/Lee (2006) for the 2002 World Cup.

7 No significant effects at all are registered for the Olympic Games. 


\section{Reasons for non-positive regional economic ef- fects of sport and sport stadia and their lack of transferability}

The econometric studies quoted above name the following as some of the reasons for the "paradoxical" negative results in Section 3:

- Associations such as the International Olympic Committee and FIFA are monopolists that award their events to the highest bidder in a procedure that bears the character of an auction. They face a large number of competing applicants that continue to raise their bids until their net advantages become negligibly small. The positive political and image effects of the sporting events inevitably lead the competing nations to carry on "raising the stakes" until the economic effects are negative. The losses of income can thus be seen as a voluntary exchange in favour of the nonpecuniary positive effects of sporting events.

- In South Africa this "price" of missing or even negative effects has only recently become clear to the city fathers affected. For example, the cities have to set up (fenced-off) fan parks in which the same advertising conditions apply. The cities also have to provide FIFA with special traffic lanes for the teams and officials, offices with unlimited telephone and internet access and other communication equipment, as well as catering, and all free of charge. However, a further two conditions are likely to cause particular problems in dynamic South Africa, whose economy is currently growing at a rate of five percent: during the entire period of the competition, no construction works are permitted in the cities.

- The sporting events require the use of public budgets that are then only available to a limited extent for other, economically more productive projects, for example in the education sector.

- As shown above with the experience of German Hotels for example. the above-mentioned prohibitions, changes in behaviour, and increases in in- 
terest rates, wages and prices can all lead to crowding out effects of regional economic activities that would otherwise have taken place in the area. In South Africa, where the construction industry is in any case working at the limits of its capacities, the displacement effect is of particular significance: the additional construction activity for stadia etc. will simply serve to reduce construction activities in other areas. Summa summarum, most ex-ante studies do not adequately take the difference between the gross and net effects into account.

- A further reason for the frequent lack of positive effects from sporting events in general has to do with the redistribution of income sometimes related to sports and sports stadia. Income redistributions can occur on the one hand from local low and normal earners in favour of a small number of sports stars who hardly spend any of their earnings in the region. On the other hand international hotel and car rental firms in particular may also profit from a World Cup, whereby it is unclear what proportion of the increased income actually remains in the region.

- A lower level of productivity on the part of workers might also result, if they are distracted from work by sport or private conversations about sport. This negative productivity effect is the downside to the general party atmosphere.

- Finally the insignificant results could simply be due to the fact that in spite of all the media attention they attract, the sporting events are just too small in comparison to the large, diverse economy within which they take place (Szymanski, 2002:177). This applies particularly when considered against the background of the relatively high level of variance of economic time series which lead to increased significance demands.

To a certain extent these sobering arguments fit in with the long tradition of economics as the "dismal science". In recent decades economics has done little to rid itself of this reputation given that it hardly ever finds any uniform, constructive and positively formulated opinions regarding the individual policy measures, events, etc. needed to achieve specific desired social effects, and this applies in 
particular to statistically-led ex-post analyses. A relatively high degree of unity is only regularly achieved regarding the specific measures and events that do not bring about any positive effects (but which ones do?).

We would like to introduce two further arguments why the sports and sports stadia we analysed can hardly display any positive effects:

- The studies relate without exception to industrialised countries. As a rule, the provision of sports venues in these countries has been very good for some time. In Germany for example there exist a total of 127,000 sports venues, including 35,000 sports halls and another 9,000 halls used for ice hockey or shooting. The figure also includes 400 multi-purpose sports halls with a spectator capacity of at least $3,000 .{ }^{8}$ Sports stadia, like most production factors, are subject to the law of diminishing returns. This includes the possibility that - given a correspondingly high level of provision - (additional) sports venues display a negative social marginal productivity. The reasons for this may for example be the follow-up costs of running and maintaining the venues, which represents a considerable burden to the local authorities concerned. ${ }^{9}$

For (developing) countries that do not have a comparably dense provision of sporting facilities at their disposal, the unsatisfactory economic consequences are probably not directly transferable.

- The sports venues studied can hardly stimulate any positive effects to the regional economy, since they were not built with this aim in mind. The aim during planning was usually to optimise the economic criteria of the professional clubs, rather than urban development. The club managers responsible had, and indeed still have, the task of maximising the profit margins for their teams. To this end they have to restrict their expenditure

8 Presentation by Patrick Roy at the yearly reunion of the working group "sports economics/ Germany" in Leipzig, april, $23^{\text {rd }} 2004$.

9 An extreme example of this is the ice arena in Bad Reichenhall in southern Germany, which collapsed due, amongst other things, to a lack of maintenance. Several people were killed. 
to the extent necessary to ensure the satisfaction of the fans. It is not their job to formulate urban and regional policies, make stadium architecture more interesting from an urban planning perspective, to add functions to the facility that are not related to the club, and to realise "external" effects for the regional economy that are of no direct benefit to their clubs. As a result the stadia are often situated in peripheral areas of the city and are not systematically embedded in any way in urban planning. They are not usually attractive places, in which people congregate outside of opening hours, or where retail traders gather and/or the value of the surrounding properties increases.

It should once again be emphasised that the club managers bear less responsibility for these developments than the local authority decisionmakers. The latter were the ones who would have had to bear the additional costs for the more sophisticated architecture (and in some cases, better locations) that would have been necessary to develop positive external effects. In view of the state of local authority coffers and the increasingly common view to be found among the population of industrialised countries that sports "millionaires" ought not to receive any more public funding, such an increased level of support would have been difficult to justify for most politicians.

An increased level of positive economic effects emanating from stadia thus presupposes that the population must accept that stadia that are efficient from a sporting technology point of view may in some cases already require public funding. If it is intended that the architecture and location should also stimulate positive urban development processes, then this necessarily involves additional costs. 


\section{Durban's plans for an iconic stadium with posi- tive regional effects}

Durban wants to become a destination for local, provincial, national and international events (venue of choice in Africa). The city regards the 2010 FIFA World Cup as a stepping stone on its way for future bids for the Commonwealth Games or Olympic Games.

Durban has been proposed as a semi-final venue and has to meet all of FIFA's requirements for a 70,000-seat arena. Nevertheless, all of the construction measures are planned not only for the FIFA World Cup, but also for future multifunctional uses, such as rugby, athletics and other events. Research thus had to be undertaken into long-term quality and sustainability. Special attention had to be made in the design process to make sure of this.

The Kings Park Stadium and its supporting facilities is intended to represent a innovation which should become the centre for sports, culture and leisure activities, representing a unique world attraction in the following years and decades. It should work as a seed for the entire development of that urban area.

To promote these targets, the city planners decided on two central characteristics of the stadium. Firstly, with regard to its architecture, the building should express an iconic statement that will stand for the city, the nation and all Africa. As South Africa often feels itself - as the flag symbolises - to consist of two nations which are coming together, it makes sense to take this process as an iconic starting point. The Arch takes up the theme of the national flag (figure 2). A clear definition of "iconic" buildings does not yet exist, but consideration of examples of this kind of building (e.g. the Sydney Opera House, the Guggenheim Museum in Bilbao, the Berlin Philharmony, the Centre Pompidou in Paris) does reveal certain common characteristics: they display an architecture that at least at the time of planning was regarded as highly innovative, often apparently "impractical", but which is unique and can be related to on human scale. The architecture gives way to a feeling of regional pride, inspiration and identification. In every case the innovative design helps the building succeed in becoming a landmark and part of 
the memorable character of the cities, which in turn succeed in "getting their name on the world map", i.e. achieve the desired image effects (Maennig, 2006a).

Secondly, Durban's urban planners also followed the insights gained from iconic buildings, most of which are within walking distance from the city center, with some directly situated by water, by deciding to locate the stadium within the city as an initiating point for the future development of urban and recreational facilities, attractive for locals as well as international tourists.

The stadium should play a lively and essential role in redeveloping the plot along the N.M.R. Avenue, the Walter Gilbert Road and the Spoornet railway lines. Figure 3 shows an aerial view. The stadium will be characterized by its central position within the larger Kings Park Sports Precinct which is currently used by the existing ABSA rugby stadium, the convention center and some minor sport facilities such as the Durban athletics Stadium and the swimming pool. 
Fig. 2: The South African Flag and the arch of Kingspark stadium

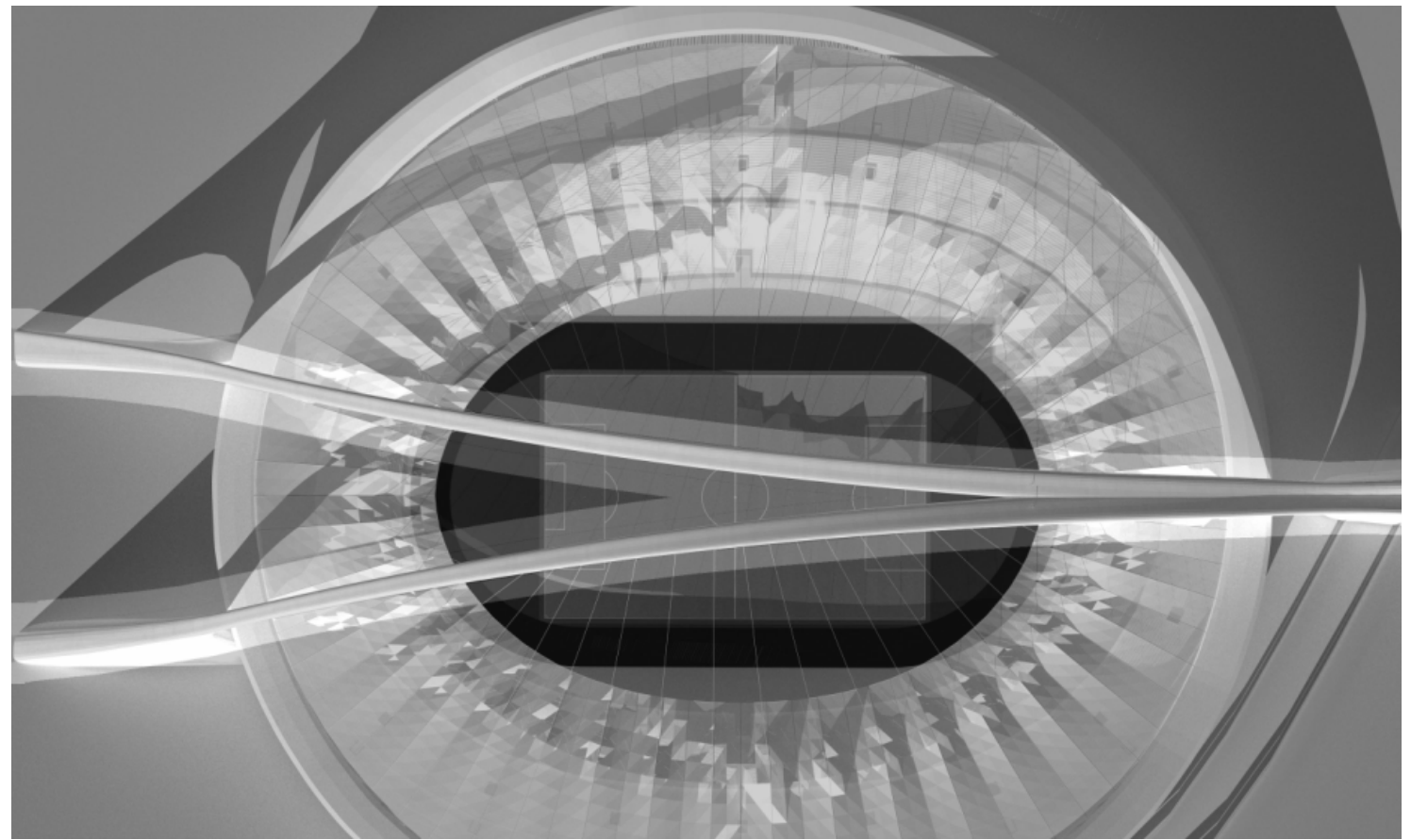

Source: Gerkan Marg \& Partners architects

Fig. 3: Areal view of Kingspark Stadium

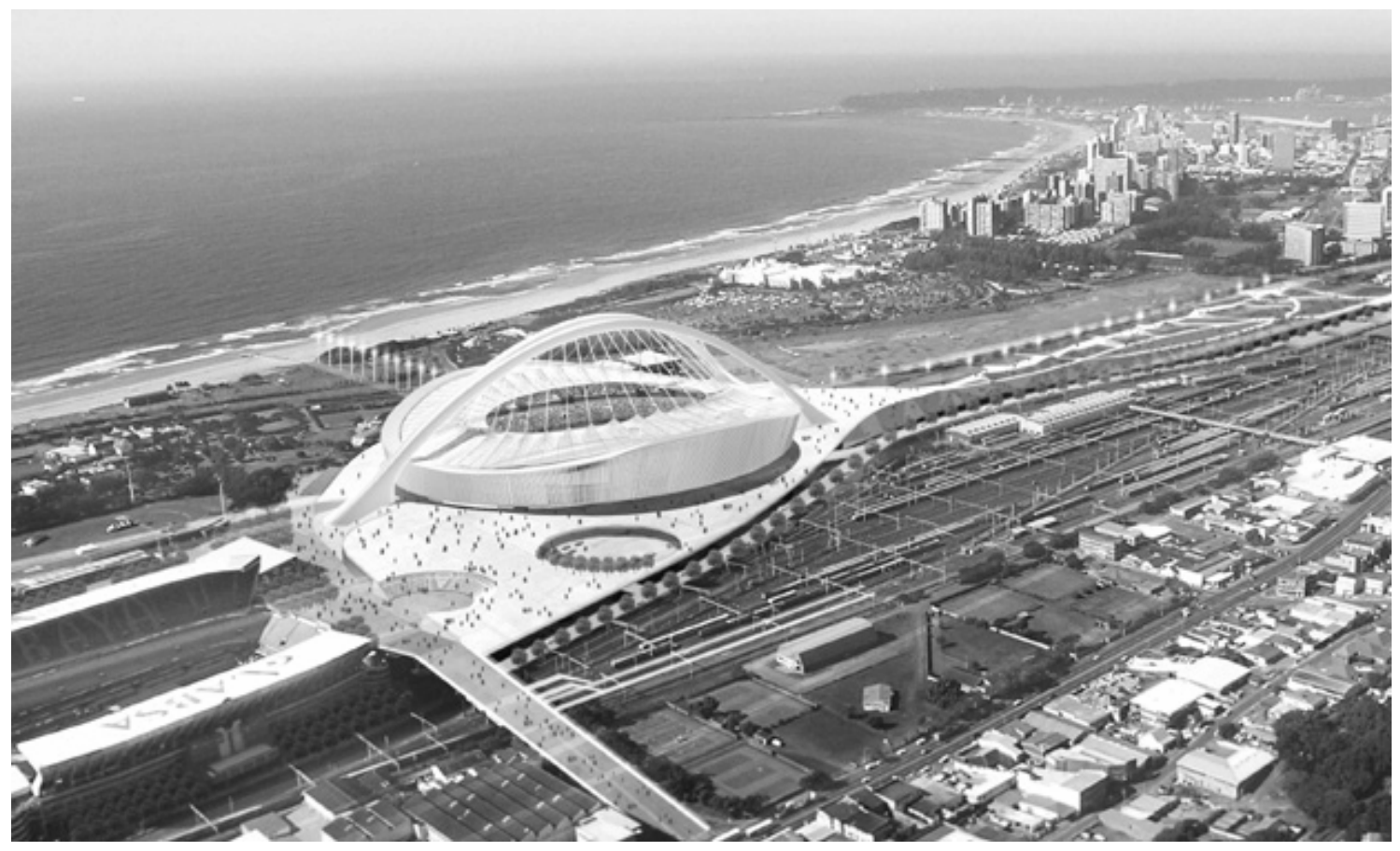

Source: Gerkan Marg \& Partners architects 
The rest of this chapter deals in more detail with the urban design (1), the framework stages of the Kings Park Sports Precinct (2), the stadium design (3), and issues of sustainability, ecology and economy (4).

\subsection{Urban design}

A primary starting point is to ensure that the stadium forms a meaningful part of the city, relating to its network of connections, visual referencing and morphology. This would suggest that the stadium is placed within a framework that takes broader city spatial structuring into consideration and where the stadium is seen as a generator for future development.

The design of the stadium at the precinct level would acknowledge that each interface and approach is unique and requires an appropriate response. The northern approach comprises contact with other sports infrastructure, the river and residential areas. The western approach and interface is contiguous with important public transport infrastructure whilst the eastern interface borders on the sea, the Golden Mile and key city arteries. The southern approach and interface is the most direct city interface (figure 4).

Ensuring sustainability and promoting ongoing activity requires that consideration be given to encouraging mixed use. Thus it is important that opportunities for a range of activities are catered for. These should include both sport and recreation-related activities as well as other activities that contribute to a vibrant public realm. Within the broader precinct, consideration therefore needs to be given to making the area a place to live, for both work and play, over time.

The specified urban design requirements will be fulfilled with the following provisions:

- The restructured district, consolidated sports precinct and public space structure would serve as a central park for Durban and collectively would form part of the "iconic" statement. 
- A hierarchy of urban functions and places would be established within the park. A key central place would be the iconic stadium and its immediate public environment.

- Establishing a range of connections would grant easy access to all facilities and ensure that the precinct will become an active part of the city, integrating a vast range of sport, commercial, and retail activities, making it a place to be visited every day.

- Establishing a powerful public space system which links existing systems such as the Golden Mile and which introduces new systems such as the Umgeni river promenade and the central sports precinct axis represents a key idea at the level of the overall precinct.

Fig. 4: Integration of the stadia into the urban design of Durban

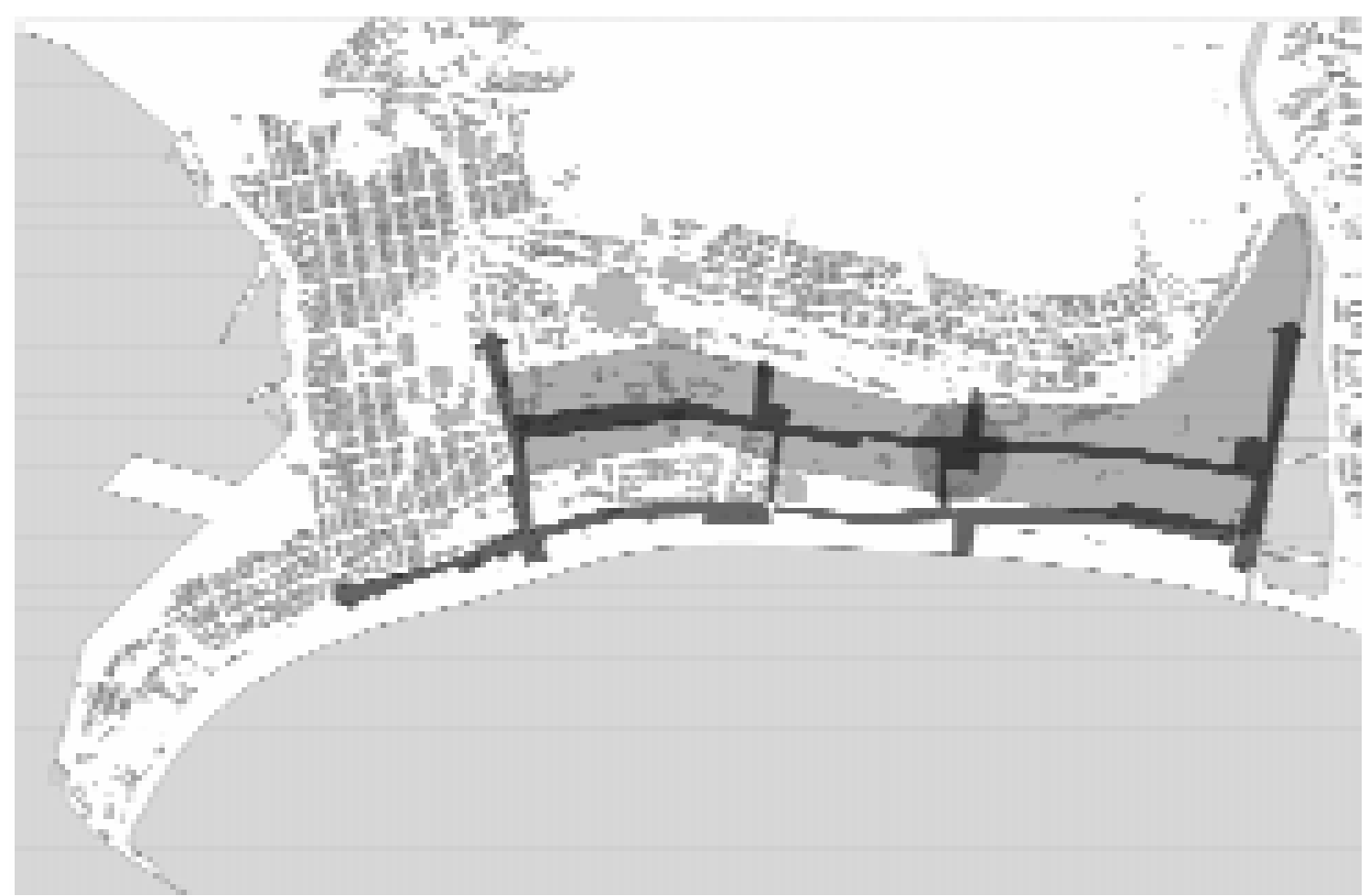

Source: Osmond Lange/NSM Designs

\subsection{Stages of frameworks}

It is important to design a plan for the incremental development and growth of the precinct. Each individual stage of this development will work separately from 
the others. The future stages will be realized depending on the interests and financial strength of the region in a timeframe of up to 15 years.

- Stage 1 until 2010 includes the minimum intervention needed for the FIFA World Cup soccer stadium to be a success. This includes the new stadium design, a pedestrian area at Walter Gilbert Road in front of the stadium towards the railway, which opens into a plaza where people can gather. The designed park offers easy connections for the spectators from the drop-off zones of the public transport systems to the arena (figure 5).

- Stage 2 until 2010 should, if possible, also be realised in time for the FIFA World Cup. It includes the following steps: the eastern axis will be extended to connect the stadium to the Indian Ocean both visually and physically. Included in the precinct are four more training fields and a northern boulevard. Enlargement and modernization of the train station is also envisaged (see figure $\mathrm{A} 1$ in the attachment).

- Stage 3 until 2015 includes the redevelopment of the precinct roads, the expansion of the sporting infrastructure, such as the modernisation of the swimming pool and athletics stadium and the extension of the Golden Mile to the north. It also includes the initiation of the development of the urban quarter that will surround and define the new park (see figure A2 in the attachment).

- Stage 4 until 2020 foresees the completion of all sports facilities required for a major sporting event such as the Commonwealth Games in keeping with all the requirements. The new urban quarter will be completed and can be used as an athletes' village for the Commonwealth or Olympic Games (see figure 6). 
Fig. 5: Stage I of the incremental development plan of Kingspark Stadium

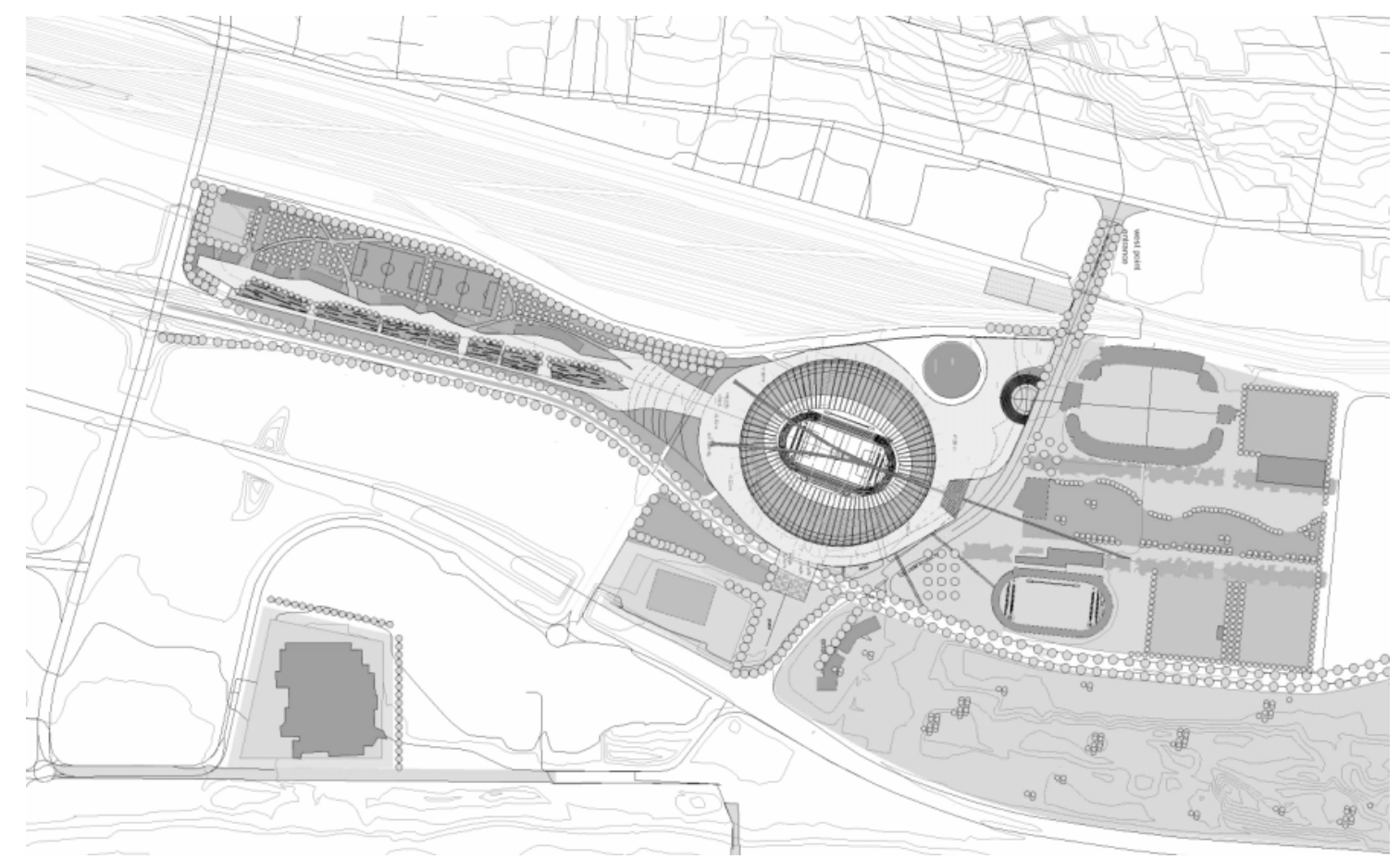

Source: Osmond Lange/NSM Designs

\subsection{Stadium design}

The center of attention and attraction will be the stadium itself! Many potential developments of the precinct will depend on the functionality and architectural quality of the arena.

The stadium creates an independent element in the complex landscape composition of the master plan. From a distance, the stadium with its grand arch will stand out with an unmistakable silhouette, inserting an imposing, monumental form into Durban's urban skyline. As one draws nearer, the fascination of the construction reveals itself and emerges as a novel, innovative building.

The lower concourse will be partially embedded in a raised platform, while two thirds of the bowl will be clearly visible, further landmarked by the arch supporting the roof structure. The raised landscape is partially filled with sports and World Cup related facilities, which can later be transformed into sports academies, VIP parking and retail towards its northern corner. In that area, an urban plaza is framed by the stadium, a smaller open air arena and additional buildings 
to the north. This area will be an attractive plaza, offering a multitude of activities for shopping, education, leisure and smaller events.

Fig. 6: Stage IV of the incremental development plan of Kingspark Stadium 2020-

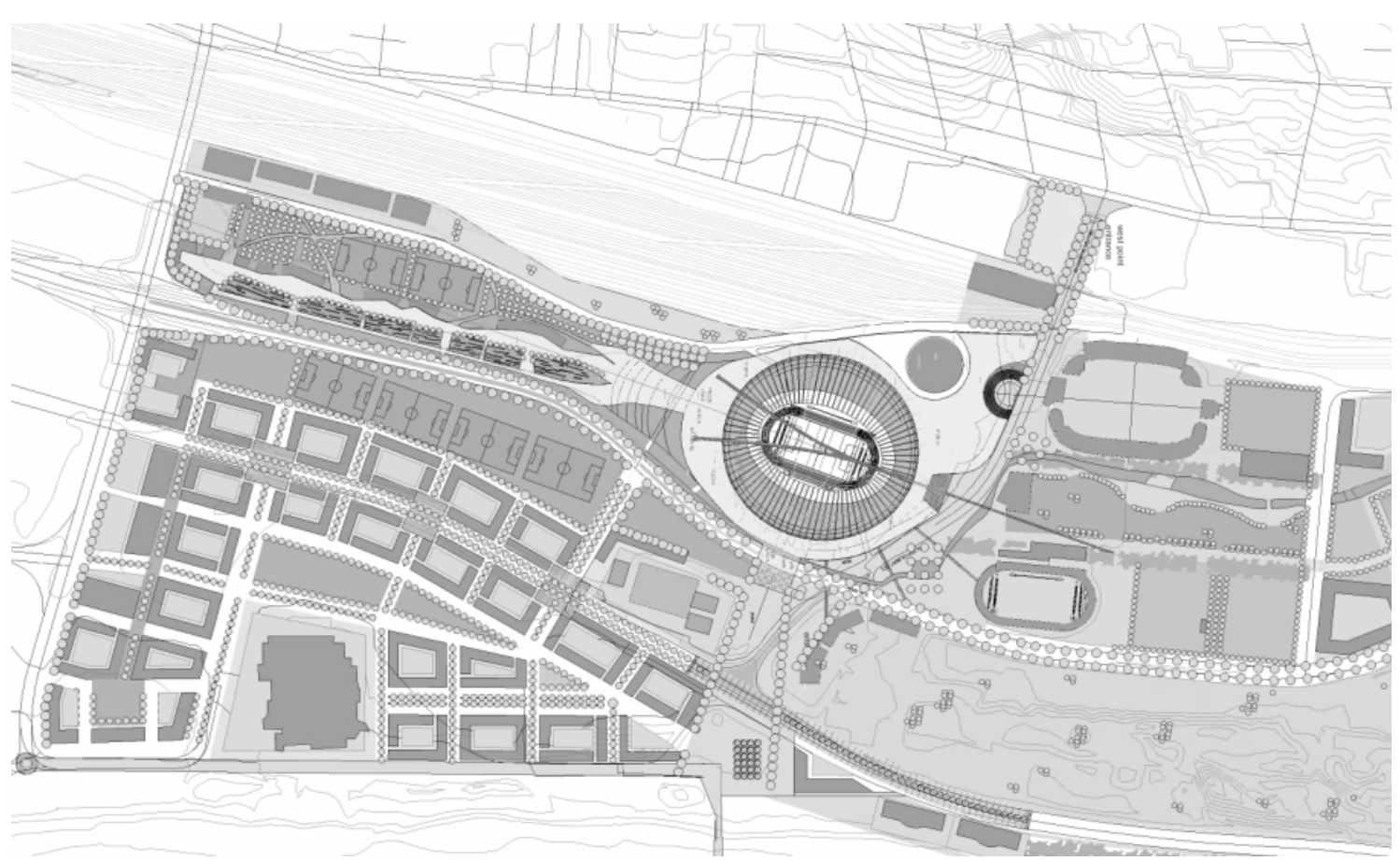

Source: Osmond Lange/NSM Designs

As a key requirement of the city, the functional units of the stadium must offer an arena with year-round operations for simultaneously occurring events on the field as well as in the multifunctional areas. ${ }^{10}$ To meet this requirement, facilities such as the sponsors' village, retail areas, an outdoor amphitheatre, restaurant and offices will be provided. All facilities can be separated and connected according to function so that year-round operation is ensured. The versatility of the building is significant for the multipurpose functionality and ease in modification in order to adapt to future developments.

The stadia bowl consists of three tiers separated by VIP or private boxes, running all around the stadia bowl. The ringed seating organization is laid out for optimal viewing and divided between the three tiers for even circulation and distribution.

${ }^{10}$ See Long (2005) who argues that multifunctional stadia were not accepted for a long period by professional sports in the US. 
The lower tier seats approximately 30,000 spectators and the middle tier another 30,000 spectators. Thanks to the flexible upper stand the spectator capacity can be adapted to the different needs of different sporting events. The upper, sloping tier provides temporary seating for an additional 10,000 spectators during the FIFA World Cup 2010 and up to 25,000 spectators for the Commonwealth Games or Olympic Games. It can be removed after the 2010 World Cup, when its concourse can then be used for additional office spaces and revenue purposes (see figure 7).

Fig. 7: Variable capacities of Kingspark Stadium

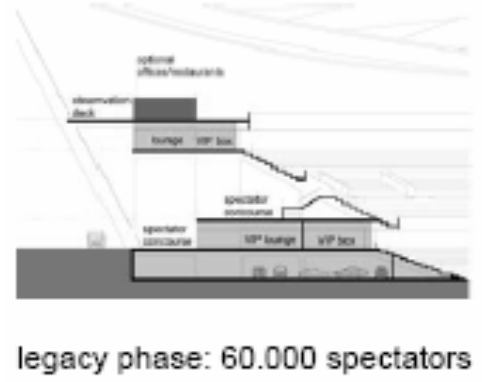

legacy phase: 60.000 spectators

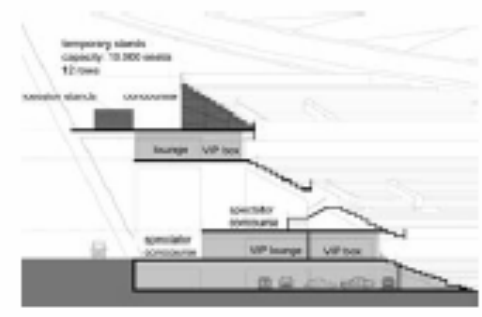

overlay phase FIFA WM: 70.000 spectators

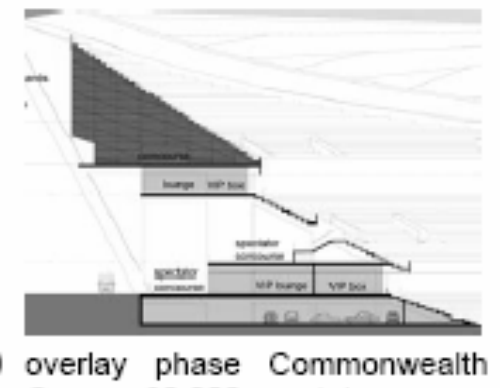

Games: 80.000 spectators

Source: Gerkan Marg \& Partners architects

Towards the back of the private boxes, business club areas cater for all VIP guests. These areas can be combined with the private boxes, offering attractive business facilities for sponsors and individual tenants. These VIP facilities ensure rental rates not only during match days but for everyday events, such as conventions, incentives or weddings.

Running all around the stadia bowl, the two rings of private boxes each offer superb viewing conditions with their fully glazed facades. The arena is designed to offer supreme viewing conditions in all sport codes for all other seats as well. The complete roof covering will create a dense and intensely atmospheric feeling 


\subsection{Sustainability, Ecology, Economy}

The stadium and its surroundings are being developed primarily to achieve the goal of a sustainable building design ${ }^{11}$ which includes the interactions between the environment, the building's structure, and its active building services. As a result of this holistic approach to planning, technical servicing to the structure will only have to be carried out when necessary. In addition, all the building sections should be operated as naturally as possible to cut back on resource consumption wherever possible. ${ }^{12}$

Both approaches, the possibility of running the building in a modular way and its natural operation will serve to reduce the operational and maintenance costs as much as possible - a long-term problem which is often overseen in the planning process. It is recognised that the net follow-up costs essentially depend on the extent to which a construction and reconstruction plan can successfully become "accepted" by the population. The fact that the chosen location and the transport connections play a considerable role is also taken into consideration. ${ }^{13}$ The followup costs could also be of considerable importance. Annual expenditure on operational costs for stadium buildings is assumed to amount to some $€ 50$ per $\mathrm{m}^{2}$ of the total of all usable surface area, calculated on the basis of regional cost estimate guidelines and assuming the (comparatively low-cost) outsourcing of cleaning work. As for the maintenance costs, these are estimated at $1.2 \%$ of the replacement value, which should be weighted according to age of the building and wear and tear resulting from use, as well as the amount of technology used. ${ }^{14}$

${ }^{11}$ For an overview on criteria of sustainability of sport stadia see Feddersen and Maennig (2003).

12 This appears important when the fact is taken into consideration that at present only a few South African sporting events apart from rugby are capable of filling the stadium to maximum capacity. Spectator figures for football are also regularly only in the five-figure area. However, South Africa's current strong growth could lead to a significant increase in the readiness of the population to pay for sporting events.

${ }^{13}$ Furthermore it is of decisive importance whether an efficiency management and/or operator model is chosen.

${ }^{14}$ The annual follow-up costs for an Olympic Stadium planned for Hamburg, which would have had its long-term capacity reduced to just 22,300 spectators $\left(135,000 \mathrm{~m}^{2}\right.$ gross floor area) following the 2012 Games, would have been up to approx. $€ 3.4$ million, cf. Maennig et al. (2002). 
The development idea can be summed up by the terms low-tech, light-tech, and high-tech. A low-tech structure is one which consciously makes use of environmental resources during the changing seasons to ensure operations. A light-tech structure is one which makes economical use of building materials, i.e. which minimizes material consumption and investment costs. High-tech components are necessary for a high-quality stadium, not only to facilitate the holding of sporting events, but to broadcast them worldwide as well.

The development of the stadium is oriented towards the requirements of Agenda 21 , which include ensuring responsible management in dealing with resources such as air, land, water, soil, and raw materials, with the priority being given to minimizing pollution, i.e. the reduction of $\mathrm{CO}^{2}$ concentrations in the atmosphere. A standard for sustainable building at the lowest operating costs possible emerges when the location's natural resources such as wind, solar energy, green spaces, rainwater and surface water, as well as geothermal energy are used, and when the building materials selected are native to the location.

To meet these requirements the building structure will

- be integrated into the ecosystem by accessing solar and wind potentials,

- seal the smallest possible land area, and change the topography in a limited and sensible way,

- provide a compact building structure,

- use passive solar energy, thermal retention and heat recovery,

- provide a connecting green recreation space,

- consume the least possible energy with the greatest possible efficiency,

- influence micro-climate via building surfaces, and optimize sun shade

All of the above measures finally result in an economically sound building structure sup-ported by an operation adaptable to the changing seasons and specifically designed to handle major events. The project's holistic approach is meant to 
create a special corporate identity, the broad shapes of the building structure contributing to the creation of a land-mark.

\section{Conclusion}

South Africa will have to invest heavily in stadia and infrastructure to hold the FIFA World Cup 2010. According to current figures, the South African government intends to spend $€ 627$ million on the ten stadia and $€ 1.6$ billion on infrastructure. The comparison with recent experiences in Germany, South Korea and Japan showed that these figures might still be too low.

However, high costs and/or resource expenditure for sport and sport stadia are not necessarily accompanied by corresponding economic benefits on the other: as a rule, academic research on the basis of econometric ex-post evaluations tends to find hardly any significantly positive income and employment effects from World Cups, Olympic Games, other large-scale sporting events and/or the associated investments in stadia.

This contribution emphasises that these results, usually from research undertaken in the USA, can only be generalised to a limited degree. In particular it is difficult to transfer them to a nation such as South Africa. The density of sports venues in countries like the USA is so high, that the marginal effects of new stadia are necessarily limited. On the other hand we also emphasise that stadium design in the USA and around the world has not hitherto adequately taken the objective of positive regional economic effects into account.

The example of Durban and its plans for a new "iconic" stadium was used to illustrate fundamental principles that have to be undertaken in order to consciously achieve positive regional economic effects. A consciously "iconic" architecture where the relevant design should not be limited to the stadium itself, but has to be embedded in a design concept for the entire urban region was shown to be of highest importance. Furthermore, we also illustrate the fact that the process of re-urbanisation of a neglected region via stadium construction cannot be under- 
stood as a short-term initiative. Rather, the development of such an area must be seen as a process taking many years and made up of several different stages or frameworks. Finally, emphasis has to be placed on the central role of the issues of sustainability, ecology and economy, without which a long-term developmental process will find it hard to survive. When the possibilities of stadia planned in such a way are taken into consideration, the right answer to the question of the effects of sport and sports stadia ought to be considerably more positive.

\section{Appendix}

Fig. A1: Stage II of the incremental development plan of Kingspark Stadium

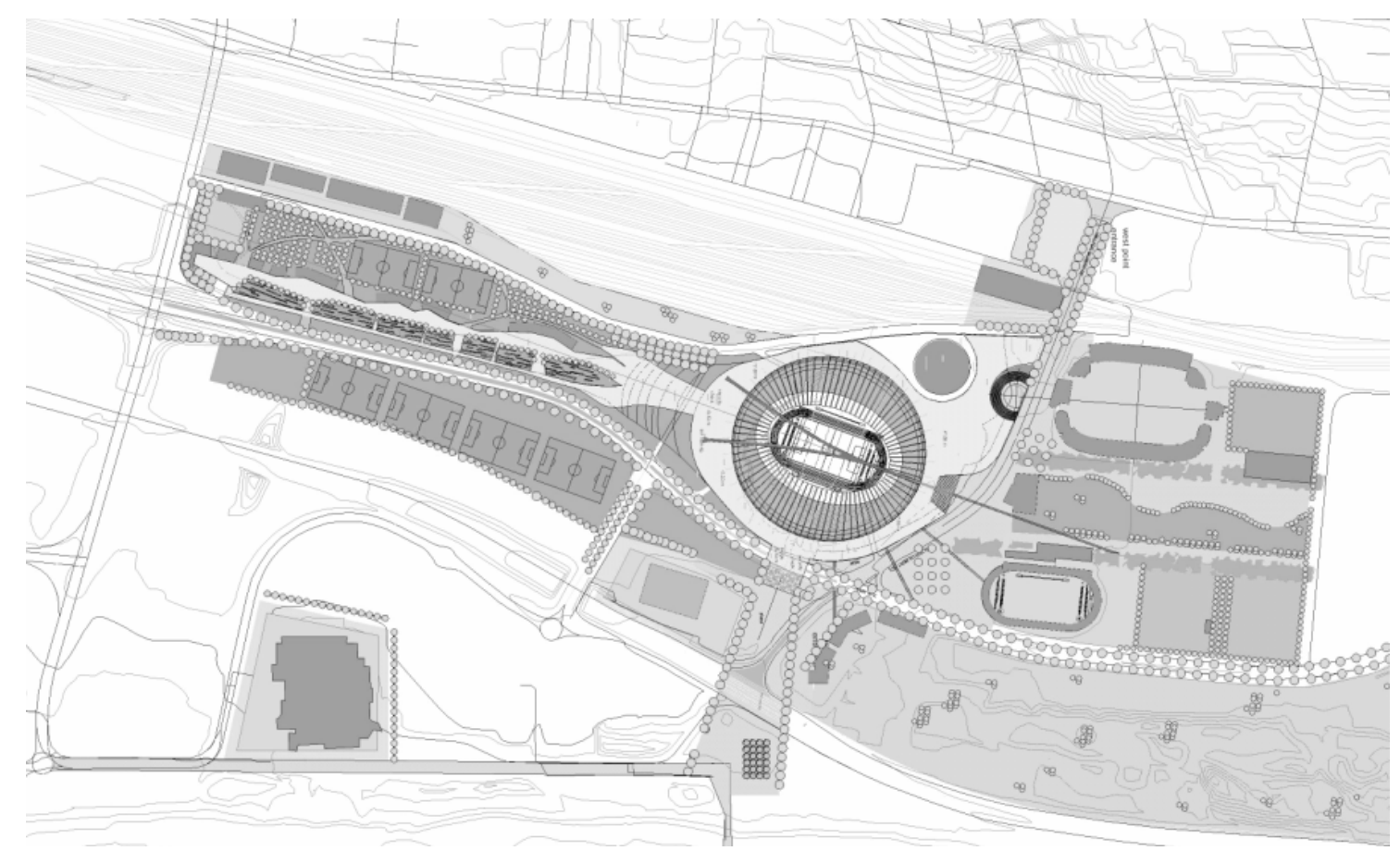

Source: Osmond Lange/NSM Designs 
Fig. A2: stage III of the incremental development plan of Kingspark Stadium

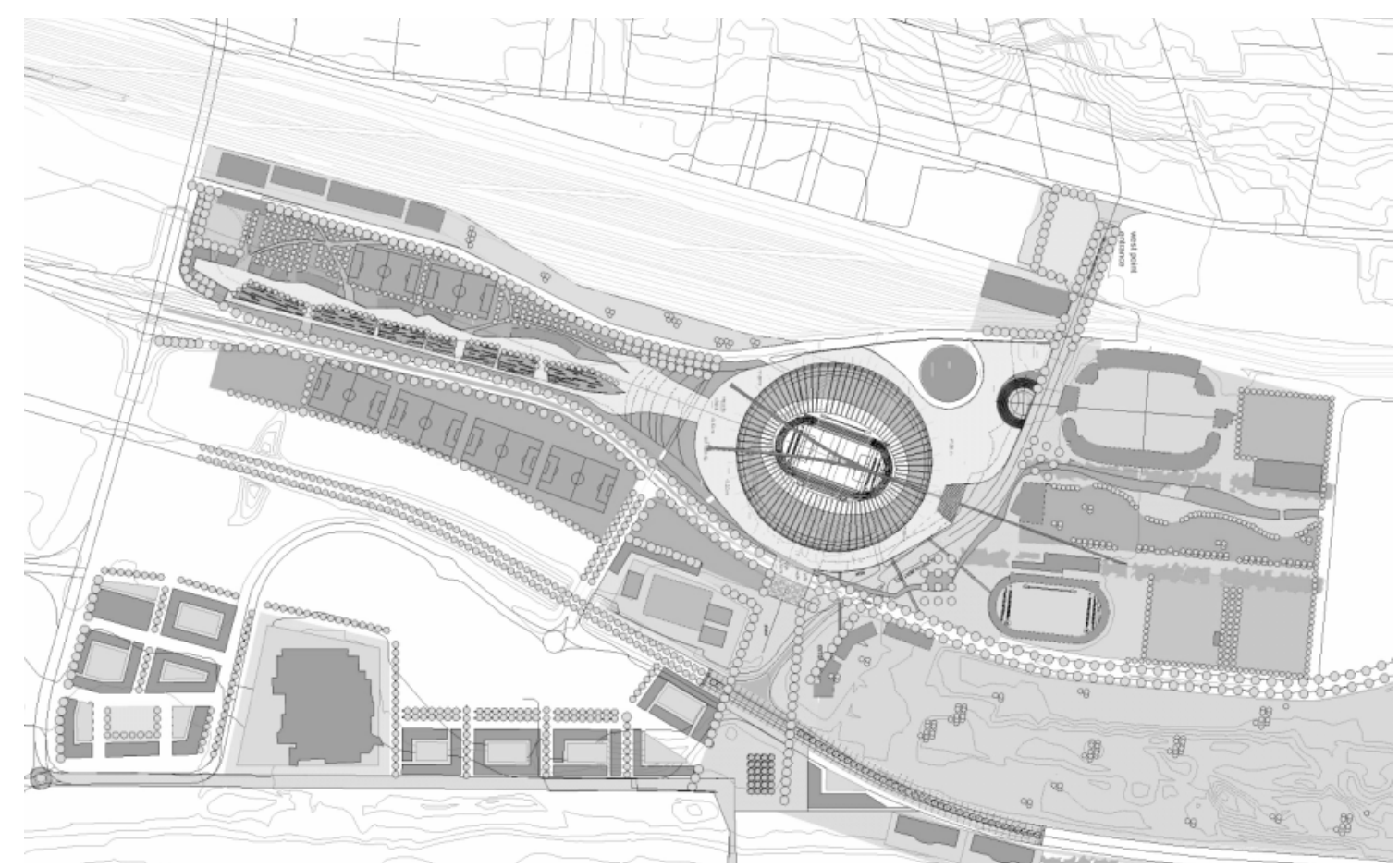

Source: Osmond Lange / NSM Designs

\section{Literature}

Ahlert G (2001). The economic effects of the soccer World Cup in Germany with regard to different financing. Economic Systems Research 13 (1):109-127.

Andranovich G, Burbank MJ, Heying CH (2001). Olympic Cities: Lessons learned from Mega-Event Politics. Journal of Urban Affairs 23(2):113-131.

Baade RA, Matheson VA (2002). Bidding for the Olympics: Fool's Gold?. In C Barros, M Ibrahímo and S Szymanski (Eds.), Transatlantic sport: the comparative economics of North American and European sports, London: Elgar, pp. 127-151.

Baade RA, Matheson VA (2004a). The quest for the cup: assessing the economic impact of the World Cup. Regional Studies, 38:343-354.

Baade RA, Matheson VA (2004b). Mega-sporting events in developing nations: playing the way to prosperity?. The South African Journal of Economics 72:1084-1095.

Baade RA, Sanderson RA (1997). The Employment Effect of Teams and Sports Facilities. In RG Noll, A Zimbalist, (Eds.), Sports, jobs and Taxes. The Economic Impact of Sports Teams and Stadiums. Washington D.C.: The Brookings Institute, pp. 92-118.

Bohlmann HR, van Heerden JH (2005). The impact of hosting a major sport event on the South African economy. University of Pretoria, Department of Economics Working Paper Series, No. 2005-09. 
Brenke K, Wagner GG (2006). Fußball-Weltmeisterschaft in Deutschland: Ein wichtiges sportliches und kulturelles Ereignis - aber ohne nennenswerte gesamtwirtschaftliche Auswirkungen (Football World Cup in Germany: an important sporting and cultural event - but without any significant macro-economic effects). DIWWochenbericht 20/2006:301-310.

Carlinho G, Coulson NE (2004). Compensating Differentials and the social benefitts of the NFL. Journal of Urban Economics 56:25-50.

Coates D, Humphreys BR (2003). Professional sports facilities, franchises and urban economic development. Public Finance and Management 3(3):335-357.

Dengel B (2006). Das Geld zu Gast bei Freunden. Financial Times Deutschland, april $13^{\text {th }}$, 2006.

du Plessis S, Maennig W (2006). Soccer World Cup 2006 in Germany and 2010 in South Africa. Similarities and differences from an economic perspective. Mimeo Stellenbosch University and Hamburg University.

Feddersen A, Maennig W (2003). Sustainability in economics - consequences for the construction of sports venues. In MP Büch, W Maennig, H.J Schulke (Eds.), Nachhaltigkeit von Sportstätten. Wissenschaftliche Berichte und Materialien des Bundesinstitut für Sportwissenschaft 12/03:11-22.

Feddersen A, Maennig W, Borcherding M (2006). The Novelty Effect of New Football Stadia: The case of Germany. International Journal of Sport Finance 1(3):174-188.

FIFA (2004). Auf nach Deutschland, Stadien (Off to Germany, stadia). <http://www.ok2006.de/stadien/ index.html>, may 12th, 2004.

Goodman R, Stern R (1994). Chicago hosts opening game of the World Cup. Illinois Parks \& Recreation 25(3).

Grant Thornton (2004). 2010 Soccer World Cup facts you should know. http://www.gauteng.net/research/pdf/soccer1.pdf, July $22^{\text {nd }}, 2006$.

Heyne M, Süssmuth B (2006). Wieviel ist den Deutschen die Ausrichtung der FIFA-WM 2006 wert und warum?. Unpublished manuscript Bremen University and University of Technologie Munich.

Hotchkiss J, Moore RE, Zobey SM (2003). Impact of the 1996 Summer Olympic Games on Employment and Wages in Georgia. Southern Economic Journal 69:691-704.

Jasmand S, Maennig W (2006). Regional Income and Employment Effects of the 1972 Munich Olympic Summer Games. Forthcoming in Regional Studies.

Kang YS, Perdue R (1994). Long-term impact of a mega-event on international tourism to the host country: a conceptual model and the case of the 1988 Seoul Olympics. Journal of the International Consumer Marketing 6:205-225.

Kasimati E (2003). Economic Aspects and the Summer Olympics: A Review of Related Research. International Journal of Tourism Research 5:433-444.

Kim HJ, Gursoy D, Lee SB (2006). The impact of the 2002 World Cup on South Korea: Comparison of pre- and post-game. Journal of Tourism Management 27:86-96.

Kim SS, Patrick JF (2005). Residents' perceptions on impacts of the FIFA 2002 World Cup: the case of Seoul as a host city. Tourism Management, 26, pp. 25-38. 
Long JG (2005). Public Funding for Major League Sports Facilities Data Services (5): A History of Public Funding, 1890 to 2005. Edward J. Bloustein School of Planning and Public Policy, Center for Urban Policy Research Working Paper Series.

Maennig W et al. (2002). Zentrale Wirtschaftlichkeitsaspekte einer bundesdeutschen Olympia-Bewerbung für 2012 (Central economic aspects of a German Olympic Bid for 2012). Expertise for Lexington $\mathrm{GmbH}$.

Maennig W (2006a). Ikonen statt Schüsseln (Icons instead of "bowls"). Immobilienmanager 7-8:32-34.

Maennig W (2006b). Fußball-WM 2010 in Südafrika: Bessere wirtschaftliche Wirkungen durch gezielte Stadionplanungen? (Soccer World Cup in South Africa: better economic effects through better targeted planning of stadia?). Afrika-Wirtschaft 4:3236.

Maennig W, Buettner N (2006). Infrastrukturinvestitionen bei Sportstadienneu-, -umund -ausbauten: Der Fall der Fußball-WM 2006 (New sport stadia and necessary investments in infrastructure: The Case of World Cup 2006 in Germany). Forthcoming in E. Thoeni (Ed.). Öffentliche Subventionen für private Sportveranstaltungen (Public support for private sport events).

Maennig W, Feddersen A (2002). Imageeffekte von Sportgroßveranstaltungen: Möglichkeiten und Grenzen der Messung (Image effects of large sport events: Scope and limits of measurement). In MP Büch, W Maennig, HJ Schulke (Eds.), Regional- und sportökonomische Aspekte von Sportgroßveranstaltungen (Regional and sport economic aspects of large sport events). Wissenschaftliche Berichte und Materialien des Bundesinstitut für Sportwissenschaft, 11/02:101-122.

McKay M, Plumb C (2001). Reaching beyond the gold - the impact of the Olympic Games on real estate markets. Jones Lang LaSalle IP, Inc.

N.N. (2006). World Cup Stadiums announced ( $7^{\text {th }}$ February, 2006), http://www. southafrica2010.org/2010stadia070206.htm, july $22^{\text {nd }}, 2006$.

Powell A (2006). Green Light for Green Point. Cape Times, july $21^{\text {st }}, 2006$, pp. 1, 6.

North DC (1955). Location Theory and Regional Economic Growth, in: Journal of Political Economy. 53:243-258.

Spilling OR (1996). Mega-Event as a Strategy for Regional Development: The Case of the 1994 Lillehammer Winter Olympics. Entrepreneurship \& Regional Development 8:321-343.

Skrentny W (2001). Das große Buch der deutschen Fußball Stadien (The big book of the German soccer stadia), Göttingen: Die Werkstatt, 2nd ed.

Szymanski S (2002). The economic Impact of the World Cup. World Economics 3(1):169177.

Teigland J (1999). Mega-Events and Impacts on Tourism: The Predictions and Realities of the Lillehammer Olympics. Impact assessment and project appraisal 17:305-317.

Tu CC (2005). How does a new sport stadium affect housing values? The case of FedEx Field. Land Economics 81(3):379-395.

Unterreiner FP (2006). Fußball-WM und Olympia: Profit und Prestige für den Gastgeber. Frankfurter Allgemeine Zeitung, March 10 ${ }^{\text {th }}, 2006$, pp 10-11. 